\title{
HIGHLIGHT
}

\section{Beta-cell apoptosis in the pathogenesis of human type 2 diabetes mellitus}

\author{
Olga Leonardi ${ }^{1}$, Gregory Mints $^{1}$ and Mehboob A Hussain ${ }^{1,2}$ \\ Departments of ${ }^{1}$ Medicine and ${ }^{2}$ Pharmacology, New York University School of Medicine, New York, USA \\ (Correspondence should be addressed to M A Hussain, 550 First Avenue MSB 424, New York, New York 10016, USA; \\ Email: hussam02@popmail.med.nyu.edu)
}

Type 2 diabetes is accompanied by chronic insulin resistance and a progressive decline in $\beta$-cell function (1). Obesity is a major risk factor for the development of type 2 diabetes $(2,3)$ and is thought to confer increased risk for type 2 diabetes through obesity-associated insulin resistance (4). However, most people who are obese do not develop diabetes but compensate their relative insulin resistance by increasing insulin secretion (5). In rodent models of obesity without diabetes there is (as opposed to non-obese littermates) an adaptive increase in $\beta$-cell mass to meet metabolic demands (6). Although not many data are available, studies suggest that $\beta$-cell mass is also adaptively increased in non-diabetic obese humans $(7,8)$. $\beta$-cell mass is regulated by a balance of $\beta$-cell replication and apoptosis, as well as development of new islets from exocrine pancreatic ducts (neogenesis) $(9,10)$. Disruption of any of the pathways of $\beta$-cell formation or increased rates of $\beta$-cell death would result in decreased $\beta$-cell mass and thus reduced capacity to produce insulin. There is controversy whether $\beta$-cell mass is decreased in type 2 diabetes mellitus $(8,11-17)$. These discrepancies are in part due to the paucity of available data in humans. Furthermore, it is controversial whether $\beta$-cell apoptosis is truly increased in type 2 diabetes.

A recent (18) very carefully conducted study gives new and convincing data indicating that increased apoptosis rather than decreased neogenesis or replication may be the main mechanism leading to reduced $\beta$-cell mass in type 2 diabetics. Autopsy material from obese patients with diabetes or with impaired fasting glucose (IFG) or without diabetes as well as from lean patients was examined. The authors report that obesity in non-diabetic humans is accompanied by a 50\% increase in relative $\beta$-cell volume as compared with lean non-diabetic humans. However, the non-diabetic obese humans died younger than the non-diabetic lean humans and the difference found on autopsy may be due to difference in age. Obese humans with IFG and type 2 diabetes had a respective 40 and $63 \%$ deficit in relative $\beta$-cell volume. The decreased $\beta$-cell volume in patients with type 2 diabetes was due to a reduced number of $\beta$-cells rather than a smaller volume of individual cells and occurred irrespectively of whether they were treated with diet alone or oral medications or insulin. There was no difference in the mean fasting plasma glucose levels among these three treatment groups. Lean subjects with type 2 diabetes had a $41 \%$ deficit in relative $\beta$-cell volume compared with lean non-diabetic subjects. These findings are consistent with other carefully conducted recent studies in which $\beta$-cell mass is decreased in type 2 diabetes $(8,15,17)$. Neogenesis, while increased in obesity, was comparable in all groups. Decreased $\beta$-cell replication was found with aging (18).

Because new islet formation, the predominant input into the $\beta$-cell mass, appears intact in type 2 diabetics (18), the mechanism for the decreased $\beta$-cell mass would have to be increased $\beta$-cell apoptosis. Indeed, a significantly increased frequency of apoptotic events were detected in lean type 2 diabetic vs non-diabetic cases. When normalized to the $\beta$-cell volume, the frequency of apoptosis was 3-fold higher in obese cases of type 2 diabetes and 10-fold higher in lean cases of type 2 diabetics as compared with their controls.

Thus, relative $\beta$-cell volume and therefore $\beta$-cell mass is decreased in both obese and lean humans with type 2 diabetes compared with non-diabetic ageand weight-matched controls. The fact that patients with IFG, a risk group for developing diabetes, had a $40 \%$ deficit in relative $\beta$-cell volume indicates that loss of $\beta$-cells is an early process in the pathogenesis of diabetes mellitus (18).

Once $\beta$-cell mass decreases below a critical level and insulin production no longer meets metabolic demands we have hyperglycemia. Does a $60 \%$ decrease in $\beta$-cell mass - as found in this study - translate into impaired glucose metabolism? Humans who have undergone $50 \%$ pancreatectomy have impaired glucose tolerance and insulin secretion in response to a hyperglycemic clamp (19-23). On this basis we may assume that a $60 \%$ reduction in $\beta$-cell mass in the face of insulin resistance may be sufficient to result in hyperglycemia.

What are the mechanisms for the increased apoptosis found in the islets of type 2 diabetics? The islet in type 2 diabetes is characterized by deposits of polypeptide (IAPP) $(15,24-29)$. This peptide causes apoptosis of $\beta$-cells $(30,31)$, particularly when it is in 
the form of small IAPP oligomers (32). In addition, both glucotoxicity and lipotoxicity cause $\beta$-cell apoptosis. The molecular mechanisms behind gluco- and lipotoxic apoptosis in the human $\beta$-cell have recently been further elucidated.

A series of studies (33-36) report on the roles of high glucose concentrations and different free fatty acids (FFAs) on $\beta$-cell proliferation, apoptosis and function in cultured human islets. The results showed that prolonged exposure of cultured human islets to high glucose levels increased $\beta$-cell apoptosis in a dosedependent manner. In addition, chronic exposure of cultured human islets to the saturated fatty acid palmitic acid results in increased markers of $\beta$-cell apoptosis and decreased $\beta$-cell proliferation. However, the monounsaturated fatty acids palmitoleic acid and oleic acid did not affect DNA fragmentation and induced $\beta$-cell proliferation. Moreover when co-supplemented, each of the monounsaturated fatty acids prevented apoptosis, prevented impairment of $\beta$-cell proliferation and improved insulin secretion that was caused by palmitic acid and/or hyperglycemia.

Federici et el. (37) have demonstrated that cultures of human pancreatic islets exposed to elevated glucose levels showed overexpression of proapoptotic genes Bad, Bid and Bik, while the expression of anti-apoptotic gene Bcl-2 was unaffected, suggesting modulation of the balance towards apoptosis and $\beta$-cell death. $\beta$-cells produce and release interleukin (IL) $-1 \beta$ in response to chronic exposure to hyperglycemia (33). This subsequently results in activation of an apoptotic pathway (NF-kB activation, FAS upregulation, DNA fragmentation) which is prevented by an IL-1 receptor antagonist. Moreover, IL-1 $\beta$-producing $\beta$-cells are reported in pancreatic sections of type 2 diabetic patients but not in normal control pancreata (33).

Chronic exposure to elevated levels of FFA leads to lipid overload of pancreatic cells, dysregulated insulin secretion $(38,39)$ and apoptotic cell death $(36,40-42)$. FFA-induced apoptosis and reduced $\beta$-cell proliferation capacity were observed in rodent $(36,41)$ and human pancreatic islets (40). Studies demonstrate that lipotoxicity is attributed to accumulation of saturated fatty acids, and not associated with exposure to unsaturated fatty acids $(36,43,44)$.

Apart from the deleterious effects of saturated fatty acids on the pancreatic $\beta$-cell, elevated serum FFAs contribute to the pathogenesis of the metabolic syndrome and heart disease. While adipocytes store excess fatty acids in the form of triglyceride in lipid droplets, non-adipose tissues have a limited capacity for storage of lipids. In hyperlipidemic states, accumulation of excess lipid in non-adipose tissues leads to cell dysfunction and/or cell death. This lipotoxicity appears to be specific for saturated fatty acids in several tissues studied and is ameliorated by unsaturated fatty acids $(36,43-46)$.
How should we understand this difference in the effects of fatty acids? In their recent work Listenberger et al. (47) provide evidence that exogenous or endogenously generated unsaturated FFAs induce incorporation of saturated fatty acids into triglycerides, thus diverting saturated fatty acids from pathways that can lead to $\beta$-cell apoptosis. In their cell culture system (47), oleic acid does not affect uptake and accumulation of palmitic acid. However, the intracellular fate of the saturated palmitic acid is altered with co-supplemented oleic acid. The presence of oleic acid resulted in incorporation of palmitate to triglyceride stores, while absence of oleic acid showed no channeling of palmitate into triglyceride stores. Appropriate controls ensured that this effect was not simply due to increased total fatty acids in the media available to cells. Moreover, cells derived from mice lacking the enzyme for the final step of triglyceride synthesis (acyl CoA:diacylglycerol transferase 1 knockout mice (48)), fail to accumulate exogenously applied fatty acid and are more sensitive to fatty acid (saturated or not)-induced cell death as compared with controls. Thus it appears that the ability to synthesize triglyceride plays an important role in the protection from lipotoxicity. Triglyceride accumulation in response to increased cellular levels of unsaturated fatty acids may be a general metabolic phenomenon. Listenberger et al. (47) hypothesize that palmitate channeled toward triglyceride storage may be unavailable for pathways leading to cell death, such as the generation of reactive intermediates and ceramide.

While we have possible mechanisms to explain glucoand lipotoxicity of $\beta$-cell apoptosis, it remains unclear what underlies the apoptotic loss of $\beta$-cells before we have frank hyperglycemia and/or hyperlipidemia. The occurrence of apoptosis in patients with IFG suggests an inherent defect in the $\beta$-cells of people who subsequently develop type 2 diabetes mellitus. A possibility for slowing the progression or even preventing type 2 diabetes may be to develop dietary and pharmacological strategies aiming at ameliorating increased $\beta$-cell apoptosis in people with a defined high risk for developing type 2 diabetes.

\section{Acknowledgements}

M A H is supported by the Juvenile Diabetes Research Foundation, the American Diabetes Association, and the National Institutes of Health.

\section{References}

1 DeFronzo RA. Lilly lecture 1987. The triumvirate: beta-cell, muscle, liver. A collusion responsible for NIDDM. Diabetes 1988 37 667-687.

2 Burke JP, Williams K, Gaskill SP, Hazuda HP, Haffner SM \& Stern MP. Rapid rise in the incidence of type 2 diabetes from 
1987 to 1996: results from the San Antonio Heart Study. Archives of Internal Medicine 1999159 1450-1456.

3 Prevention CfDCa. Trends in the prevalence and incidence of self reported diabetes mellitus: United States, 1980-1994. Morbidity and Mortality Weekly Report 199746 1014-1018.

4 Ludvik B, Nolan JJ, Baloga J, Sacks D \& Olefsky J. Effect of obesity on insulin resistance in normal subjects and patients with NIDDM. Diabetes 199544 1121-1125.

5 Polonsky KS. Dynamics of insulin secretion in obesity and diabetes. International Journal of Obesity and Related Metabolic Disorders 200024 (Suppl 2) S29-S31.

6 Flier SN, Kulkarni RN \& Kahn CR. Evidence for a circulating islet cell growth factor in insulin-resistant states. PNAS 200198 $7475-7480$.

7 Ogilvie RF. The islands of Langerhans in 19 cases of obesity. Journal of Pathology $193337473-481$.

8 Kloppel G, Lohr M, Habich K, Oberholzer M \& Heitz PU. Islet pathology and the pathogenesis of type 1 and type 2 diabetes mellitus revisited. Survey and Synthesis of Pathology Research $19854110-125$

9 Finegood DT, Scaglia L \& Bonner-Weir S. Dynamics of beta-cell mass in the growing rat pancreas. Estimation with a simple mathematical model. Diabetes $199544249-256$.

10 Bonner-Weir S. Islet growth and development in the adult. Journa of Molecular Endocrinology 200024 297-302.

11 Maclean N \& Ogilvie RF. Quantitative estimation of the pancreatic islet tissue in diabetic subjects. Diabetes $1955 \mathbf{4}$ 367-376.

12 Stefan Y, Orci L, Malaisse-Lagae F, Perrelet A, Patel Y \& Unger RH. Quantitation of endocrine cell content in the pancreas of nondiabetic and diabetic humans. Diabetes 198231 694-700.

13 Saito K, Yaginuma N \& Takahashi T. Differential volumetry of A $\mathrm{B}$ and D cells in the pancreatic islets of diabetic and nondiabetic subjects. Tohoku Journal of Experimental Medicine 1979129 273-283.

14 Rahier J, Goebbels RM \& Henquin JC. Cellular composition of the human diabetic pancreas. Diabetologia 198324 366-371.

15 Clark A, Wells CA, Buley ID, Cruickshank JK, Vanhegan RI, Matthews DR et al. Islet amyloid, increased A-cells, reduced B-cells and exocrine fibrosis: quantitative changes in the pancreas in type 2 diabetes. Diabetes Research 19889 151-159.

16 Guiot Y, Sempoux C, Moulin P \& Rahier J. No decrease of the beta-cell mass in type 2 diabetic patients. Diabetes 200150 (Suppl 1) S188.

17 Sakuraba H, Mizukami H, Yagihashi N, Wada R, Hanyu C \& Yagihashi S. Reduced beta-cell mass and expression of oxidative stress-related DNA damage in the islet of Japanese type II diabetic patients. Diabetologia $2002 \mathbf{4 5} 85-96$.

18 Butler AE, Janson J, Bonner-Weir S, Ritzel R, Rizza RA \& Butler PC Beta-cell deficit and increased beta-cell apoptosis in humans with type 2 diabetes. Diabetes 200352 102-110.

19 Dresler CM, Fortner JG, McDermott K \& Bajorunas DR. Metabolic consequences of (regional) total pancreatectomy. Annals of Surgery $1991214131-140$.

20 Robertson RP, Lanz KJ, Sutherland DE \& Seaquist ER. Relationship between diabetes and obesity 9 to 18 years after hemipancreatect omy and transplantation in donors and recipients. Transplantation $200273736-741$.

21 Seaquist ER, Kahn SE, Clark PM, Hales CN, Porte D Jr \& Robertson RP. Hyperproinsulinemia is associated with increased beta cell demand after hemipancreatectomy in humans. Journal of Clinical Investigation 199697 455-460.

22 Seaquist ER, Pyzdrowski K, Moran A, Teuscher AU \& Robertson RP. Insulin-mediated and glucose-mediated glucose uptake following hemipancreatectomy in healthy human donors. Diabetologia 199437 1036-1043.

23 Seaquist ER \& Robertson RP. Effects of hemipancreatectomy on pancreatic alpha and beta cell function in healthy human donors. Journal of Clinical Investigation 199289 1761-1766.
24 O'Brien TD, Butler AE, Roche PC, Johnson KH \& Butler PC. Islet amyloid polypeptide in human insulinomas. Evidence for intracellular amyloidogenesis. Diabetes 199443 329-336.

25 Westermark P \& Wilander E. The influence of amyloid deposits on the islet volume in maturity onset diabetes mellitus. Diabetologia $197815417-421$.

26 Howard CF Jr. Longitudinal studies on the development of diabetes in individual Macaca nigra. Diabetologia 198629 301-306.

27 Howard CF Jr \& Van Bueren A. Changes in islet cell composition during development of diabetes in Macaca nigra. Diabetes 198635 $165-171$.

28 de Koning EJ, Bodkin NL, Hansen BC \& Clark A. Diabetes mellitus in Macaca mulatta monkeys is characterised by islet amyloidosis and reduction in beta-cell population. Diabetologia 199336 $378-384$.

29 Cooper GJ, Willis AC, Clark A, Turner RC, Sim RB \& Reid KB. Purification and characterization of a peptide from amyloid-rich pancreases of type 2 diabetic patients. PNAS $1987 \mathbf{8 4}$ $8628-8632$.

30 Lorenzo A, Razzaboni B, Weir GC \& Yankner BA. Pancreatic islet cell toxicity of amylin associated with type- 2 diabetes mellitus. Nature 1994368 756-760.

31 Schubert D, Behl C, Lesley R, Brack A, Dargusch R, Sagara Y et al. Amyloid peptides are toxic via a common oxidative mechanism. PNAS 199592 1989-1993.

32 Janson J, Ashley RH, Harrison D, McIntyre S \& Butler PC. The mechanism of islet amyloid polypeptide toxicity is membrane disruption by intermediate-sized toxic amyloid particles. Diabetes 199948 491-498.

33 Maedler K, Sergeev P, Ris F, Oberholzer J, Joller-Jemelka HI, Spinas GA et al. Glucose-induced beta cell production of IL-1beta contributes to glucotoxicity in human pancreatic islets. Journal of Clinical Investigation $2002110851-860$.

34 Maedler K, Fontana A, Ris F, Sergeev P, Toso C, Oberholzer J et al. FLIP switches Fas-mediated glucose signaling in human pancreatic beta cells from apoptosis to cell replication. PNAS $2002998236-8241$.

35 Maedler K, Spinas GA, Lehmann R, Sergeev P, Weber M, Fontana A et al. Glucose induces beta-cell apoptosis via upregulation of the Fas receptor in human islets. Diabetes 2001 50 1683-1690.

36 Maedler K, Spinas GA. Dyntar D, Moritz W, Kaiser N \& Donath MY. Distinct effects of saturated and monounsaturated fatty acids on beta-cell turnover and function. Diabetes 200150 69-76.

37 Federici M, Hribal M, Perego L, Ranalli M, Caradonna Z, Perego C et al. High glucose causes apoptosis in cultured human pancreatic islets of Langerhans: a potential role for regulation of specific Bcl family genes toward an apoptotic cell death program. Diabetes 200150 1290-1301.

38 Prentki M, Vischer S, Glennon MC, Regazzi R, Deeney JT \& Corkey BE. Malonyl-CoA and long chain acyl-CoA esters as metabolic coupling factors in nutrient-induced insulin secretion. Journal of Biological Chemistry 1992267 5802-5810.

39 Zhou YP \& Grill V. Long term exposure to fatty acids and ketones inhibits B-cell functions in human pancreatic islets of Langerhans. Journal of Clinical Endocrinology and Metabolism $1995801584-1590$.

40 Lupi R, Dotta F, Marselli L, Del Guerra S, Masini M, Santangelo C et al. Prolonged exposure to free fatty acids has cytostatic and pro-apoptotic effects on human pancreatic islets: evidence that beta-cell death is caspase mediated, partially dependent on ceramide pathway, and Bcl-2 regulated. Diabetes $2002 \quad 51$ 1437-1442.

41 Piro S, Anello M, Di Pietro C, Lizzio MN, Patane G, Rabuazzo AM et al. Chronic exposure to free fatty acids or high glucose induces apoptosis in rat pancreatic islets: possible role of oxidative stress. Metabolism 200251 1340-1347.

42 Shimabukuro M, Zhou YT, Levi M \& Unger RH. Fatty acid-induced beta cell apoptosis: a link between obesity and diabetes. PNAS 199895 2498-2502. 
43 de Vries JE, Vork MM, Roemen TH, de Jong YF, Cleutjens JP, van der Vusse GJ et al. Saturated but not mono-unsaturated fatty acids induce apoptotic cell death in neonatal rat ventricular myocytes. Journal of Lipid Research 199738 1384-1394.

44 Cnop M, Hannaert JC, Hoorens A, Eizirik DL \& Pipeleers DG. Inverse relationship between cytotoxicity of free fatty acids in pancreatic islet cells and cellular triglyceride accumulation. Diabetes $2001501771-1777$.

45 Hardy S, Langelier Y \& Prentki M. Oleate activates phosphatidylinositol 3-kinase and promotes proliferation and reduces apoptosis of MDA-MB-231 breast cancer cells, whereas palmitate has opposite effects. Cancer Research 200060 6353-6358.
46 Listenberger LL, Ory DS \& Schaffer JE. Palmitate-induced apoptosis can occur through a ceramide-independent pathway. Journal of Biological Chemistry 2001276 14890-14895.

47 Listenberger LL, Han X, Lewis SE, Cases S, Farese RV Jr, Ory DS et al. Triglyceride accumulation protects against fatty acidinduced lipotoxicity. PNAS $1003077-3082$.

48 Smith SJ, Cases S, Jensen DR, Chen HC, Sande E, Tow B et al. Obesity resistance and multiple mechanisms of triglyceride synthesis in mice lacking Dgat. Nature Genetics 20001 87-90.

Received 13 May 2003

Accepted 26 May 2003 